\title{
«Populational» model of kimberlites : an application to diamondiferous kimberlites of regions with various geodynamic history.
}

\author{
Budaev, D.A.
}

United Institute of Geology, Geophysics and Mineralogy SB RAS, Novosibirsk, 630090, Russia

Petrochemical features of kimberlites from main diamond deposits of Yakutia having been investigated, simultaneous character of distributions of rock - forming oxides and coincidence of distributions' extremums have been observed. Stability of these peculiarities relatively to vast number of cases (totally as much as 5,600 Xray-fluorescence analyses have been examined) has made possible to form hypothesis suggested by occurrence of stable rock varieties among diamondiferous kimberlites likely biological populations [Vasilenko,Kuznetsova,1986;Vasilenko,1995]. As a whole, 7 kimberlite «populations» have been separated, and main interpopulational variability agency has been refered to as $\mathrm{TiO}_{2}$ content (table 1). It was $\mathrm{CaO} / \mathrm{MgO}$ ratio that has been suggested to be main factor of diversity within each «population».

Table1. Average compositions of kimberlite populations of Yakutia [Vasilenko, 1995].

\begin{tabular}{|l|l|l|l|l|l|l|}
\hline Populations & 1 & 2 & 3 & 4 & 5 & 6 \\
\hline $\mathrm{n}$ & 331 & 1443 & 535 & 440 & 435 & 259 \\
\hline $\mathrm{SiO} 2$ & 25,96 & 27,53 & 28,92 & 30,27 & 28,15 & 28,58 \\
\hline $\mathrm{TiO} 2$ & 0,43 & 0,86 & 1,18 & 1,43 & 1,73 & 2,09 \\
\hline $\mathrm{Al} 2 \mathrm{O} 3$ & 2.64 & 2.25 & 2.12 & 2,11 & 1,74 & 1,99 \\
\hline $\mathrm{Fe} 2 \mathrm{O} 3$ & 4,73 & 6,53 & 7,71 & 8,06 & 7,81 & 9.30 \\
\hline $\mathrm{MgO}$ & 22,52 & 26.40 & 28,37 & 29,19 & 28,30 & 30,44 \\
\hline $\mathrm{CaO}$ & 16,15 & 13,64 & 10,58 & 9,34 & 10,46 & 7,91 \\
\hline $\mathrm{Na} 2 \mathrm{O}$ & 0,52 & 0,16 & 0,17 & 0,18 & 0,14 & 0,18 \\
\hline $\mathrm{K} 2 \mathrm{O}$ & 0.83 & 0,50 & 0,54 & 0,53 & 0,22 & 0,53 \\
\hline $\mathrm{P} 2 \mathrm{O} 5$ & 0,50 & 0,30 & 0,38 & 0.34 & 0,27 & 0.47 \\
\hline
\end{tabular}

Analysis of general features of populational model has shown that decrease of $\mathrm{TiO}_{2}$ average contents in «popultions» is accomplished by decrease of $\mathrm{Fe}_{2} \mathrm{O}_{3}$ average contents and elevation of $\mathrm{Al}_{2} \mathrm{O}_{3}, \mathrm{~K}_{2} \mathrm{O}$ contents, and diamondiferousness [Vasilenko et al,1994; Vasilenko, 1995; Vasilenko et al, 1996]. Mechanism of this phenomenon is believed to has been determined by changing of clinopyroxene $(\mathrm{CPx})$ composition with depth increase. $\mathrm{CPx}$, in turn, is assumed to be main (with olivine) source of kimberlite smelts have been formed by partial melting of mantle matter.

Results of number of experiments [Solov'eva et al, 1994; Ringwood, 1975] as well as investigations of composition of CPx from diamond - bearing parageneses [Sobolev, 1974] suggest that under high pressures $\mathrm{CPx}$ contains elevated admixture of $\mathrm{Al}_{2} \mathrm{O}_{3}$ and jadeite; moreover, $\mathrm{K}$ jadeite has been founded in $\mathrm{CPx}$ constitution under pressure higher than $40 \mathrm{Kbars}$. Ultra-high pressures give rise to dissolving of titano-magnetite in $\mathrm{CPx}$; and this solid solution finally transforms to garnet. Behaviour of $\mathrm{Ti}$ in solid solution Perovskite+CPx under ultra-high pressures is believd to be simultaneous with that in CPx.

Mentioned above data show that with increase of depth $\mathrm{Ti}$ has contained in pressure-stable phases (garnet). As a results, deepmore smelts become enriched by $\mathrm{Al}_{2} \mathrm{O}_{3}, \mathrm{~K}_{2} \mathrm{O}$ and exhausted by $\mathrm{TiO}_{2}$, unlike to restites.

Populational model of kimberlite constitution makes possible to compare petrochemical features of kimberlites of various regions on the base of statistically correct juxtaposition. Taking 
into account mentioned above, it means comparison of features of geodynamic history and genesis. Furthermore, investigation of kimberlites within concrete province (field) may be substituted by studying of only one separate pipe with the same set of «populations».

E.g., petrochemical peculiarities of diamondiferous kimberlites of Yakutia, South Africa, Lesotho, and West Africa have been investigated. Kimberlites of African regions prove to be characterized by the same populational structure, as Yakutian ones (tables 2-4). Some differences have been occurred are caused by abundance of concrete «populations» which, in turn, are depended on tectonic position of regions have been dealed with ( craton areas for Yakutia and South Africa, transition craton-middleproterozoic orogenetic belt for Lesotho, continental margin for West Africa) during kimberlite intrusions epochs [Janse, 1984].

Table 2. Average compositions of kimberlite populations of South Africa.

\begin{tabular}{|l|l|l|l|l|l|l|l|}
\hline Populations & 1 & 2 & 3 & 4 & 5 & 6 & 7 \\
\hline $\mathrm{n}$ & & $64^{*}$ & $42^{*}$ & 8 & $18^{*}$ & $21^{*}$ & $34^{*}$ \\
\hline $\mathrm{SiO} 2$ & & 33.91 & 37.93 & 33.20 & 35.49 & 29.23 & 33.63 \\
\hline $\mathrm{TiO} 2$ & & 0.68 & 0.96 & 1.41 & 1.76 & 2.09 & 2.43 \\
\hline $\mathrm{AL2O} 3$ & & 4.32 & 5.05 & 3.88 & 3.49 & 2.30 & 3.68 \\
\hline $\mathrm{Fe} 2 \mathrm{O} 3$ & & 6.29 & 6.02 & 5.64 & 6.21 & 5.42 & 7.71 \\
\hline $\mathrm{MgO}$ & & 18.63 & 23.51 & 25.70 & 23.64 & 28.61 & 24.21 \\
\hline $\mathrm{CaO}$ & & 12.85 & 6.56 & 8.47 & 9.96 & 11.66 & 9.34 \\
\hline $\mathrm{Na2O}$ & & 0.28 & 0.99 & 0.52 & 0.43 & 0.25 & 0.43 \\
\hline $\mathrm{K} 2 \mathrm{O}$ & & 0.95 & 1.07 & 2.44 & 1.63 & 0.89 & 1.81 \\
\hline $\mathrm{P} 2 \mathrm{O} 5$ & & 0.59 & 0.56 & 1.58 & 1.14 & 1.07 & 1.51 \\
\hline
\end{tabular}

Table 3. Average compositions of kimberlite populations of West Africa.

\begin{tabular}{|l|l|l|l|l|l|l|l|}
\hline Populations & 1 & 2 & 3 & 4 & 5 & 6 & 7 \\
\hline $\mathrm{n}$ & 3 & $33^{*}$ & $13^{*}$ & $13^{*}$ & $37^{*}$ & $21^{*}$ & $12^{*}$ \\
\hline $\mathrm{SiO} 2$ & 40.82 & 37.09 & 36.92 & 35.20 & 33.22 & 32.37 & 31.99 \\
\hline $\mathrm{TiO} 2$ & 0.36 & 0.78 & 1.07 & 1.34 & 1.68 & 2.17 & 2.63 \\
\hline $\mathrm{A} 2 \mathrm{O} 3$ & 8.22 & 4.01 & 5.18 & 4.81 & 4.84 & 3.15 & 2.85 \\
\hline $\mathrm{Fe} 2 \mathrm{O} 3$ & 6.51 & 5.57 & 7.64 & 6.91 & 7.25 & 8.49 & 6.63 \\
\hline $\mathrm{MgO}$ & 22.40 & 28.55 & 24.19 & 21.51 & 24.92 & 28.31 & 27.00 \\
\hline $\mathrm{CaO}$ & 2.97 & 5.21 & 6.89 & 10.43 & 8.24 & 6.37 & 7.42 \\
\hline $\mathrm{Na} 2 \mathrm{O}$ & 0.65 & 0.54 & 0.95 & 0.82 & 0.27 & 0.32 & 0.31 \\
\hline $\mathrm{K} 2 \mathrm{O}$ & 1.04 & 1.03 & 1.46 & 1.81 & 1.52 & 1.13 & 0.74 \\
\hline $\mathrm{P} 2 \mathrm{O} 5$ & 0.23 & 0.35 & 0.59 & 0.61 & 0.57 & 0.87 & 0.57 \\
\hline
\end{tabular}

Table 4. Average compositions of kimberlite populations of Lesotho.

\begin{tabular}{|l|l|l|l|l|l|l|l|}
\hline Populations & 1 & 2 & 3 & 4 & 5 & 6 & 7 \\
\hline $\mathrm{n}$ & & & & 4 & 3 & 4 & 9 \\
\hline $\mathrm{SiO} 2$ & & & & 32.14 & 31.55 & 29.68 & 31.85 \\
\hline $\mathrm{TiO} 2$ & & & & 1.42 & 1.79 & 2.08 & 2.67 \\
\hline $\mathrm{Al2O} 3$ & & & & 2.38 & 3.44 & 3.74 & 4.22 \\
\hline $\mathrm{Fe} 2 \mathrm{O} 3$ & & & & 5.48 & 4.26 & 6.50 & 7.59 \\
\hline $\mathrm{MgO}$ & & & & 29.29 & 31.09 & 23.56 & 23.52 \\
\hline $\mathrm{CaO}$ & & & & 8.05 & 7.13 & 10.09 & 8.77 \\
\hline $\mathrm{Na2O}$ & & & & 0.11 & 0.19 & 0.15 & 0.17 \\
\hline $\mathrm{K} 2 \mathrm{O}$ & & & & 2.04 & 1.34 & 0.39 & 1.15 \\
\hline $\mathrm{P} 2 \mathrm{O} 5$ & & & & 0.81 & 0.74 & 0.84 & 0.24 \\
\hline
\end{tabular}

* - averages by pipe has been used as well as simple analyses 
Shift of «population» sets passing from Lesotho to South African kimberlites correlates with data of lithosphere thickness (150 and $180 \mathrm{~km}$ accordingly) [Solov'eva et al, 1994]. The same depth (180-175 km) for lithosphere boundary has been observed for Udachnaya kimberlite pipe in Yakutia which populational structure completely coincides with that of South African kimberlites. West African kimberlites differ by multipopulational composition with high alkali content of $4^{\text {th }}, 5^{\text {th }}$ and $7^{\text {th }}$ «populations». These petrochemical features make kimberlites of West Africa close to Mir pipe kimberlites [Vasilenko et al, 1996], and simultaneously may be explaned by impurity of unexhausted material [Vasilenko et al, 1996].

\section{References:}

Janse A.J.A. 1984, Kimberlites-where and when. In: Glover J.E., Harris P.G. (Eds.) Kimberlite occurrence and origin : a basis for conceptual models in exploration. Univ.West.Austral., Publ. \#8, pp. 81-94

Solov'eva L.V, Vladimirov B.M, Dneprovskaya L.V, et al.,1994, Kimberlites and kimberlite-like rocks...: Novosibirsk, Nauka, 256 p. (in Russian)

Ringwood A.E., 1975, Composition and petrology of the Earth's mantle : McGraw-Hill, New-York, 600 p.

Sobolev N.V., 1974, Deep-seated inclusions in kimberlites and the problem of the composition of upper mantle : Novosibirsk, Nauka,263 p. (in Russian)

Vasilenko V.B., Kuznetsova L.G., 1986, Soviet Geology and Geophysics, \#7, pp. 85-98

Vasilenko V.B., Zinchuk N.N., Kuznetsova L.G., et al., 1994, Trans. Russian Acad. Sci., vol. 338 , pp. $85-88$

Vasilenko V.B., 1995, Petrochemistry of the major diamond deposits of Yakutia. In: Kimberlites of Yakutia (6th Int. Kimb. Conf. Guide Book),Novosibirsk : pp.46-59

Vasilenko V.B., et al., 1996, Russian Geology and Geophysics, vol. 37, \# 2 